\title{
Interleukin-1 receptor antagonist production in cultured synovial cells from patients with rheumatoid arthritis and osteoarthritis
}

\author{
Yosuke Fujikawa, Masao Shingu, Takehiko Torisu, Shogo Masumi
}

\begin{abstract}
Objective-To measure the amounts of interleukin-1 receptor antagonist (IL-1ra) protein produced by cultured synovial cells obtained from patients with rheumatoid arthritis (RA) and osteoarthritis (OA). Methods-Synovial cells obtained from patients with either RA or OA were cultured and the supernatants were measured for IL-1ra by enzyme linked immunosorbent assay.

Results-The synovial cells obtained from patients with $R A$ produced significantly smaller amounts of IL-1ra than did those obtained from patients with $O A$, in a late passage (third to fifth) without stimulation and a first passage both with and without stimulation $(p<0.025$, respectively). In addition, when the patients with $R A$ were divided into two groups according to the maximum number of lining cell layers, the amounts of IL-1ra produced by the proliferative type were smaller than those produced by the less proliferative type $(p<0 \cdot 025)$.

Conclusions-The above findings suggest that IL-1ra production in RA synovial cells is suppressed, and that reduced IL-1ra protein production is one of the causes which leads to the proliferation of lining cells and persistent joint inflammation.
\end{abstract}

(Ann Rheum Dis 1995; 54: 318-320)

Rheumatoid arthritis (RA) is a systemic autoimmune disease characterised primarily by chronic inflammatory synovitis which often leads to joint destruction. Cytokines have been implicated as important mediators of both inflammation and joint destruction in RA. ${ }^{1}$ Interleukin-1 (IL-1) is thought to mediate tissue damage in $\mathrm{RA}$ by inducing prostaglandin $\mathrm{E}_{2}$ $\left(\mathrm{PGE}_{2}\right)$ and neutral protease production in synovial fibroblasts and articular chondrocytes. ${ }^{2}$

IL-1 receptor antagonist (IL-1 ra) has been demonstrated to block the effects of IL-1 in various in vitro systems and animal disease models, and also to have no immunological cross reactivity with either IL- $1 \alpha$ or IL- $1 \beta .{ }^{3-6}$ It is thus possible that sustained active synovitis is attributable not only to an excess production of agonist, but also to an inadequate synthesis of antagonist protein.

To investigate the possible role of IL-1 ra in RA, the amounts of IL-1ra protein produced by cultured synovial cells from patients with
RA and osteoarthritis (OA) were measured by an enzyme linked immunosorbent assay (ELISA).

\section{Patients and methods}

Synovial tissue specimens were obtained from 18 patients (10 with RA and eight with OA) at the time of knee joint replacement. Each patient satisfied the diagnostic criteria of the American College of Rheumatology. ${ }^{7}$ All RA patients were treated with prednisolone, disease modifying antirheumatic drugs (DMARDs) and non-steroidal anti-inflammatory drugs (NSAIDs). All OA patients took NSAIDs without taking prednisolone.

HISTOLOGICAL ANALYSIS OF SYNOVIAL

MEMBRANES

The synovial membranes of 10 patients with RA were fixed in neutral phosphate buffered $10 \%$ formalin and sections were stained with haematoxylin and eosin. The sections were examined without knowledge of either the patient's identity or the grade of joint damage. The degree of synovial lining cell proliferation was measured as the maximum number of synovial lining cell layers, and the degree of lymphocyte infiltration was graded from 1 to 4 depending on the number of infiltrated cells. ${ }^{9} 10$

SYNOVIAL CELL CULTURE

The synovial cells were cultured as previously described. ${ }^{11}$ Cells taken at the first and the late (third to fifth) subcultures were examined by immunohistochemistry. ${ }^{12}$ The first passage of rheumatoid synovial tissue cells comprises approximately $40-50 \%$ macrophages and $50-60 \%$ fibroblast like cells. The first passage of OA synovial tissue has a slightly greater percentage of macrophages $(60-70 \%)$. The cells from both RA and OA synovium obtained at late passage consisted mostly of synovial fibroblasts like cells $(>95 \%)$.

Aliquots of the cells $\left(0.5 \mathrm{ml}, 1 \times 10^{5}\right.$ cells $\left./ \mathrm{ml}\right)$ were plated in a 24 well plate and cultured for five to seven days until the cells reached confluency, at which time the number of cells in each well averaged $1 \cdot 8-2 \cdot 0 \times 10^{5}$ cells/well. The medium was replaced with $0.5 \mathrm{ml}$ of fresh medium and the cells cultured on at $37^{\circ} \mathrm{C}$ in a $5 \%$ carbon dioxide incubator for 72 hours in the presence of lipopolysaccharide (LPS, Sigma Chemical Co, St Louis, Missouri, $10 \mu \mathrm{g} / \mathrm{ml}$ ) or 
phosphate buffered saline (PBS) $(0.01 \mathrm{~mol} / \mathrm{l}$ phosphate, $0.138 \mathrm{~mol} / \mathrm{l} \mathrm{NaCl}, \mathrm{pH} \quad 7 \cdot 4$ ) (unstimulated controls). The plates were then centrifuged at $400 \mathrm{~g}$ for 10 minutes and the supernatants collected and frozen at $-80^{\circ} \mathrm{C}$ until required for assay for IL-1ra.

\section{MEASUREMENT OF CYTOKINES}

IL-1 ra, IL- $1 \alpha$ and IL- $1 \beta$ were measured by ELISA kits (Amersham International plc, Amersham, England, for IL-1ra; Ohtsuka Pharmaceutical Co, Tokyo, Japan, for IL-1 $\alpha$ and IL-1 $\beta$ ). These assays recognise both natural and recombinant IL-1 ra, IL-1 $\alpha$, or IL-1 $\beta$. No significant cross reactivity or interference was observed. The lower limits of detection of these kits are IL- $1 \mathrm{ra} 6.5 \mathrm{pg} / \mathrm{ml}, \mathrm{IL}-1 \alpha 0.5 \mathrm{pg} / \mathrm{ml}$, and IL-1 $\beta 0.5 \mathrm{pg} / \mathrm{ml}$.

\section{STATISTICAL ANALYSIS}

Data are expressed as mean (SD). Statistical analyses were by Student's $t$ test.

\section{Results}

The figure shows the amounts of IL-1ra produced by synovial cells $\left(2 \times 10^{5}\right.$ cells/well $)$. Unstimulated synovial cells of the first passage obtained from patients with RA produced less IL-1 ra $(214.0 \quad(157 \cdot 0) \mathrm{pg} / \mathrm{ml}, \mathrm{n}=10)$ than unstimulated synovial cells of the first passage obtained from patients with $\mathrm{OA}$ $(659.0 \quad(686.4) \mathrm{pg} / \mathrm{ml}, \mathrm{n}=8) \quad(\mathrm{p}<0.025)$. Similarly, stimulated synovial cells of the first passage from patients with RA produced significantly smaller amounts of IL-1 ra $(301.6(217.4) \mathrm{pg} / \mathrm{ml}, \mathrm{n}=10)$ than $\mathrm{did}$ those cells obtained from patients with OA

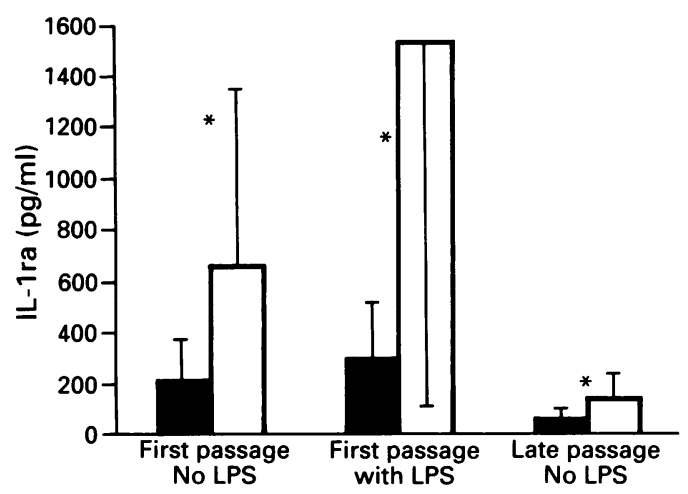

IL-1ra production (mean, SD) by synovial cells. Synovial cells of the first passage obtained from patients with either rheumatoid arthritis ( $\square)(n=10)$ or osteoarthritis ( $\square)$ $(n=8)$ were cultured $\left(2 \times 10^{5}\right.$ cells per well $)$ with or without lipopolysaccharide (LPS) $10 \mu \mathrm{g} / \mathrm{ml}$; synovial cells of the late passage were also cultured, without LPS. IL-1ra was measured in the supernatants.

${ }^{*} p<0.025$ between groups.

Histological findings in synovial membranes from patients with rheumatoid arthritis

\begin{tabular}{llll}
\hline & No of patients & Lining cell layer & $\begin{array}{l}\text { Production of IL-1 ra } \\
(p g / m l)\end{array}$ \\
\hline Proliferative group & 7 & $6 \cdot 4(1 \cdot 0)$ & $126 \cdot 7(72 \cdot 6)$ \\
Less proliferative group & 3 & $2 \cdot 7(0 \cdot 5)^{\star}$ & $458 \cdot 3(156 \cdot 8)^{\star}$ \\
\hline
\end{tabular}

Values are mean (SD). ${ }^{\star} \mathrm{p}<0.05$ compared with proliferative group.
$(1526.5(1415 \cdot 4) \mathrm{pg} / \mathrm{ml}, \mathrm{n}=8)(\mathrm{p}<0.025)$. In late passage, unstimulated cells from patients with RA also produced significantly smaller amounts of IL-1 ra (57.2 (39.9) pg/ml, $\mathrm{n}=10)$ than did synovial cells from patients with $\mathrm{OA}$ $(136.6(100 \cdot 7) \mathrm{pg} / \mathrm{ml}, \mathrm{n}=8) \quad(\mathrm{p}<0.025)$. When the delta values of IL-1 ra production attributable to LPS stimulation were calculated, those for synovial cells obtained from $\mathrm{RA}$ patients $(46 \cdot 2(36 \cdot 2) \mathrm{pg} / \mathrm{ml}, \mathrm{n}=10)$ were statistically smaller than those for OA patients $(201 \cdot 1(188 \cdot 8) \mathrm{pg} / \mathrm{ml}, \mathrm{n}=8)(\mathrm{p}<0.0125)$.

The production of IL- $1 \alpha$ by cultured synovial cells from patients with $\mathrm{RA}$ and $\mathrm{OA}$ examined by ELISA was almost undetectable. Greater amounts of IL- $1 \beta$ were produced by synovial cells obtained from patients with RA $(1.58(1.34) \mathrm{pg} / \mathrm{ml}, \mathrm{n}=5)$ than by those from patients with OA $(0.76(0.45) \mathrm{pg} / \mathrm{ml}, \mathrm{n}=5)$ and the ratios of IL-1 $\beta$ to IL-1 ra concentrations for each cell culture were greater in $\mathrm{RA}\left(4.42(3.25) \times 10^{-3}, \mathrm{n}=5\right)$ than in OA $\left(2.89(2.07) \times 10^{-3}, \mathrm{n}=5\right)$. However, these differences in both IL-1 $\beta$ production and IL-1 $\beta$ :IL-1 ra ratio were not statistically significant.

No clinical parameter (erythrocyte sedimentation rate, $C$ reactive protein, rheumatoid factors, platelet count, haemoglobin concentration, leucocyte count, joint score, duration of morning stiffness, strength of hand grip, and activity index) was found to correlate with the amount of IL-1 ra produced by stimulated or unstimulated synovial cells of the first passage obtained from patients with RA (data not shown).

When patients with RA were compared in two groups according to the maximum number of lining cell layers (proliferative group $=$ more than four layers; less proliferative group $=$ fewer than three layers), the amounts of IL-1 ra produced by synovial cells from the proliferative group $(126.7(72.6) \mathrm{pg} / \mathrm{ml}, \mathrm{n}=7)$ were found to be significantly smaller than those from the less proliferative group $(458.3(156.8) \mathrm{pg} / \mathrm{ml}, \mathrm{n}=3)(\mathrm{p}<0.025)$ (table). However, there was no correlation between the degree of lymphocyte infiltration and the amount of IL-1ra produced by the synovial cells obtained from RA.

\section{Discussion}

This is the first report of IL-1 ra protein production by cultured synovial cells obtained from patients with RA and OA using a sensitive and specific sandwich ELISA. Malyak et al ${ }^{13}$ reported that IL-1ra concentrations in RA synovial fluid were increased compared with $\mathrm{OA}$ and other non-inflammatory arthropathies, and they suggested that the increased concentrations of IL-1 ra in RA synovial fluid might not be adequate to block the proinflammatory effects of IL-1 within the synovial tissue. Our own experimental study of IL-1 ra production by RA peripheral blood mononuclear cells (submitted for publication) indicated that IL-1 ra production by those cells was increased compared with normal peripheral blood mononuclear cells. However, Deleuran et al, ${ }^{14}$ using 
monoclonal antibodies and immunohistochemical techniques, demonstrated that there was a greater number of cells containing IL-1 ra in the OA synovium than in the RA synovium. Their results also suggested that RA synovial cells, which proliferated in rheumatoid joints, produced smaller amounts of IL-1 ra than did OA synovial cells. Our comparative study between RA and OA showed that the amounts of IL-1 ra produced by synovial cells obtained from patients with RA were decreased compared with those obtained from patients with OA. These results support those of Deleuran et al and thus also imply a possible role of IL-1 ra in RA.

All the patients with RA in this study were treated with prednisolone and DMARDs; none of the patients with OA was receiving these medications. Our study confirmed that glucocorticoids suppressed production of IL-1 ra by cultured synovial cells. It is possible that the suppression of IL-1 ra production by cultured synovial cells from patients with RA was the result of an in vivo effect of glucocorticoids. Alternatively, suppression of IL-1 ra production may be implicated as part of the pathogenesis of RA, in which case past treatment with oral glucocorticoids and DMARDs would have little influence on the production of IL-1 ra by cultured synovial cells.

A primary characteristic of RA synovial tissue is proliferating synovial cells. ${ }^{1}$ IL-1 can stimulate fibroblast growth ${ }^{15}$ and induce production of collagenase and $\mathrm{PGE}_{2}{ }^{1}$ in synovial cultures. Muirden et $a l^{9}$ reported that joint damage recorded by surgeons correlated directly with the grade of lining cell proliferation. Our results also showed that the amounts of IL-1ra produced by the proliferative group of patients were significantly smaller than those produced by the less proliferative group. This reduced production of IL-1 ra would exacerbate any underlying biological effects of IL-1 on the pathological processes occurring in rheumatoid joints.

In conclusion, we have demonstrated reduced IL-1 ra production by cultured synovial cells obtained from patients with RA in comparison with cells from patients with OA. These findings suggest that reduction in the amount of IL-1 ra produced may be one cause for both the proliferation of lining cells and persistent joint inflammation.

1 Dayer J M, de Rochemonteix B, Burrus B, Demcznk S, Dinarello C A. Human recombinant interleukin 1 stimulates collagenase and prostaglandin $E_{2}$ production by human synovial cells. $\mathcal{F}$ Clin Invest $1986 ; 77$ : 645-8.

2 Dinarello C A. Interleukin-1 and its biologically related cytokines. Adv Immunol 1989; 44: 153-205.

3 Arend W P. Interleukin 1 receptor antagonist: a new member of the interleukin 1 family. $\mathcal{F}$ Clin Invest 1991, 88: $1445-51$.

4 Arend W P, Dayer J-M. Cytokines and cytokine inhibitors or antagonists in rheumatoid arthritis. Arthritis Rheum or antagonists in

5 Smith R J, Chin J E, San L M, Justen J M. Biologic effects of an interleukin-1 receptor antagonist protein on interleukin-1 stimulated cartilage erosion and chondrocyte responsiveness. Arthritis Rheum 1991; 34: 78-83.

6 Arend W P, Smith M F Jr, Janson R W, Joslin F G. IL-1 receptor antagonist and IL-1 $\beta$ production in human monocytes are regulated differently. F Immunol 1991; 147: 1530-6.

7 Arnett F C, Edworthy S M, Bloch D A, et al. The American Rheumatism Association 1987 revised criteria for the classification of rheumatoid arthritis. Arthritis Rheum 1987; 31: 315-24.

8 Altman R, Asch E, Bloch D, et al. Development of criteria for the classification and reporting of osteoarthritis: classification of osteoarthritis of the knee. Arthritis Rheum 1986; 29: $1039-49$.

9 Muirden K D, Mills K W. Do lymphocytes protect the rheumatoid joint? BMF 1971; 23: 219-21.

10 Haraoui B, Pelletier J P, Cloutier J M, Faure M P Pelletier J M. Synovial membrane histology and immunopathology in rheumatoid arthritis and osteoarthritis. Arthritis Rheum 1991; 34: 153-63.

11 Tawara $T$, Shingu $M$, Nobunaga $M$, Naono T. Effects of recombinant human IL-1 $\beta$ on production of prostaglandin $\mathrm{E}_{2}$, leukotriene $\mathrm{B}_{4}, \mathrm{NAG}$, and superoxide by human synovial cells and chondrocytes. Inflammation 1991; 15: 145-57.

12 Alvaro-Gracia J M, Zvaifler N J, Firestein G S. Cytokines in chronic inflammatory arthritis. V. Mutual antagonism between interferon-gamma and tumor necrosis factoralpha on HLA-DR expression, proliferation, collagenase production, and granulocyte macrophage colonyproduction, and granulocyte macrophage colonystimulating factor production by rheumatoid
synoviocytes. F Clin Invest 1990; 86: 1790-8.

13 Malyak M, Swaney R E, Arend W P. Levels of synovial fluid interleukin-1 receptor antagonist in rheumatoid arthritis and other arthropathies. Arthritis Rheum 1993; 36: $781-9$.

14 Deleuran B W, Chu C Q, Field M, et al. Localization of interleukin-1 $\alpha$, type 1 interleukin-1 receptor antagonist in the synovial membrane and cartilage/pannus junction in rheumatoid arthritis. Brf Rheumatol 1992; 31: 801-9.

15 Schmidt F A, Mizel S B, Cohen D, Green T. Interleukin 1. A potent regulator of growth. F Immunol 1982; 128: $2177-82$. 